\title{
Prokrastinasi Akademik Mahasiswa Tingkat Akhir pada Masa Pandemi COVID-19
}

\author{
Academic Procrastination of the Final-Year Undergraduate Students during \\ COVID-19 Pandemic
}

\author{
Riza Noviana Khoirunnisa, Miftakhul Jannah, Damajanti Kusuma Dewi, Satiningsih \\ Program Studi Psikologi Universitas Negeri Surabaya, Indonesia
}

\begin{abstract}
The COVID-19 pandemic is currently affecting education bodies including universities. The negative impacts of pandemic on students' academic lives cannot be underestimated primarily on the final-year undergraduate students who are working on their thesis. Various obstacles encountered by the students due to the distance learning applied by universities in responding to the pandemic can cause academic problems including procrastination. The main impact of academic procrastination on students is the delay in graduation that affects both the students' future careers and the image of the university. The study aims to describe the academic procrastination of the finalyear students during the COVID-19 pandemic. This was a survey research that applied saturated samples for recruiting subjects. A number of 224 final-year students were involved. Data was collected using an academic procrastination questionnaire and was analysed descriptively using a statistic program. The results showed that the academic procrastination among the participants was in the moderate category. The residence of the participants who are working on their thesis from homes indicate the connection with academic procrastination. In contrast, gender and the entry year are not proved as the factors that affect the students' academic procrastination.
\end{abstract}

Keywords: Academic procrastination, COVID-19 pandemic, students

\begin{abstract}
Abstrak: Pandemi COVID-19 telah berdampak pada pendidikan tinggi. Dampak negatif tidak dapat diabaikan dalam kegiatan pembelajaran terlebih pada mashasiswa semester akhir yang sedang mengerjakan skripsi. Berbagai kendala yang ditemui mahasiswa menimbulkan prokrastinasi akademik. Dampak dari prokrastinasi akademik adalah tertundanya kelulusan yang mempengaruhi baik masa depan mahasiswa maupun citra perguruan tinggi. Penelitian ini bertujuan untuk mengetahui gambaran prokrastinasi akademik mahasiswa tingkat akhir dalam masa pandemi COVID-19. Penelitian ini menggunakan metode survei yang merekrut subjek menggunakan teknik sampling jenuh dengan jumlah subjek penelitian sebesar 224 orang. Data dikumpulkan menggunakan skala prokrastinasi akademik dan dianalisis secara deskriptif dengan bantuan program statistik. Hasil penelitian menunjukkan prokrastinasi akademik pada subjek berada pada kategori sedang. Tempat tinggal ditemukan menjadi faktor yang berkaitan dengan prokrastinasi akademik selama mengerjakan skripsi dari rumah. Namun, jenis kelamin dan tahun masuk universitas tidak terbukti sebagai faktor yang mempengaruhi prokrastinasi akademik mahasiswa.
\end{abstract}

Kata kunci: Prokrastinasi akademik, pandemi COVID-19, mahasiswa

Korespondensi tentang artikel ini dapat dialamatkan kepada Riza Noviana Khoirunnisa melalui email: rizakhoirunnisa@unesa.ac.id 
Pandemi COVID-19 telah menimbulkan dampak krusial terhadap pembelajaran pada seluruh jenjang pendidikan termasuk perguruan tinggi. Perguruan tinggi memberlakukan pembelajaran jarak jauh dalam upaya tetap menjaga kualitas pendidikan nya. Pembelajaran jarak jauh ini merupakan pembelajaran yang menggunakan sarana atau media, terutama berbasis internet, yang memungkinkan adanya interaksi antara pengajar dan pembelajar (Prawiyogi et al., 2020)

Pembelajaran jarak jauh di perguruan tinggi dilakukan dengan tujuan untuk mengurangi resiko dari penularan COVID-19. Pembelajaran dilakukan tanpa harus bertemu secara langsung namun dapat tetap berinteraksi dan mengoptimalkan online platform. Pembelajaran jarak jauh dapat mereduksi penularan COVID-19 karena tidak mengharuskan orang bertemu tatap muka antara pendidik, peserta didik, dan tenaga kependidikan (Suryono, 2020)

Namun, pembelajaran jarak jauh dapat menimbulkan dampak negatif pada mahasiswa seperti ketidaksiapan sarana dalam mengikuti pembelajaran online, merasa bosan dengan kegiatan pembelajaran yang monoton, sulit memahami materi, merasa kurang mampu mengatur waktu, kurang mampu mengatur diri dalam belajar, dan merasa cemas (Suhadianto et al., 2020). Jika tidak dapat ditangani dengan baik, semua dampak tersebut pada akhirnya dapat menyebabkan risiko adanya penundaan dalam penyelesaian tugas atau disebut juga prokrastinasi akademik pada mahasiswa. Menurut Argaheni (2020), pembelajaran online berdampak pada mahasiswa, yaitu menimbulkan kebingungan, menjadi pasif, kurang kreatif dan produktif, terjadi penumpukan informasi atau konsep, dan mengalami stres. Berdasarkan penelitian oleh Tazer et al. (2020), siswa yang menggunakan internet lebih dari 4 jam akan cenderung menggunakannya secara menyimpang dan menunjukkan prokrastinasi akademik yang lebih tinggi dibanding siswa yang menggunakan internet di bawah lama waktu tersebut. Hal ini menunjukkan bahwa penggunaan internet dalam pembelajaran jarak jauh berpeluang untuk disalahgunakan untuk mengakses hal lain yang tidak relevan dengan belajar dan tidak digunakan untuk kepentingan pembelajaran.

Dampak diberlakukannya pembelajaran jarak jauh sebagai respon terhadap pandemi COVID-19 ini juga dirasakan oleh mahasiswa. Dampak ini menjadi lebih krusial terutama pada mahasiswa tingkat akhir yang harus menyelesaikan tugas akhir atau skripsi tepat waktu. Pembelajaran jarak jauh akibat pandemi ini menimbulkan kurang kondusifnya lingkungan pembelajaran mahasiswa tingkat akhir yang membutuhkan bimbingan intensif dengan dosen dan interaksi positif dengan sesama mahasiswa tingkat akhir. Selain itu, pembatasan sosial yang diberlakukan otoritas selama masa pandemi telah memberikan hambatan tersendiri. Mahasiswa tingkat akhir yang semula sudah merencanakan target untuk seminar proposal, pengambilan data, sidang skripsi, dan target kelulusan pada akhirnya harus terhambat dikarenakan akses masuk lokasi penelitian ditutup sebagai akibat dari kebijakan physical distancing sehingga mengalami keterbatasan gerak dalam pengambilan data dan pencarian sumber referensi penulisan skripsi. Selain itu, beban mental juga muncul pada mahasiswa yang ingin mewujudkan harapan dan keinginan orang tua untuk lulus tepat waktu, dan tidak membayar uang kuliah lagi tidak dapat dipenuhi oleh mahasiswa.

Kendala-kendala tersebut memungkinkan mahasiswa yang sedang mengerjakan skripsi melakukan penundaan terhadap pengerjaan skripsi yang telah diprogram di awal semester ketika memprogram Kartu Rencana Studi (KRS). Penyelesaian skripsi sendiri dalam kondisi normal sudah memberikan tantangan bagi mahasiswa, terlebih lagi saat ini penyelesaian tersebut dilakukan secara online. Tidak sedikit mahasiswa yang mengalami hambatan dalam penyelesaian skripsi yang menyebabkan mahasiswa menjadi lama dalam masalah kelulusan. 
Mahasiswa seharusnya mampu menyelesaikan studi strata satu (S1) dalam waktu 4 tahun, dapat men-jadi lebih lama hingga sampai 7-10 tahun (Godfrey, 1991)

Solomon dan Rothblum (1984) menjelaskan bahwa prokrastinasi akademik merupakan penundaan dalam menyelesaikan tugas akademik, seperti menunda mengerjakan latihan soal, menunda mencari berbagai referensi untuk keperluan pembuatan makalah, menunda untuk mengurus keperluan administrasi terkait dengan sekolah. Pychyl et al. (2000) juga mengungkapkan bahwa perilaku menunda adalah suatu perilaku dimana individu seharusnya dapat mengerjakan tugas di waktu itu, akan tetapi individu memilih untuk mengerjakan di lain waktu dengan mengganti waktu yang seharusnya dipergunakan untuk mengerjakan tugas dengan sesuatu yang membawa kesenangan seperti bermain. Burka dan Yuen (1983) menjelaskan bahwa prokrastinasi merupakan penundaan untuk melakukan sesuatu pekerjaan sampai waktu atau hari berikutnya. Selanjutnya, Burka dan Yuen (1983) menambahkan beberapa fakta dalam sebuah penegasan bahwa terdapat cara berpikir irasional yang dimiliki oleh seorang prokrastinator. Seorang prokrastinator memiliki kemungkinan tentang sudut pandang yang berbeda bahwa suatu tugas harus diselesaikan dengan sempurna sehingga dia merasa lebih aman untuk tidak menyelesaikan dengan segera.

Prokrastinasi akademik cenderung cukup tinggi di kalangan mahasiswa. Alasan para mahasiswa menunda mengerjakan tugas adalah karena merasa tidak sedang diawasi (Handoyo et al., 2020). Hal ini terjadi ketika pembelajaran jarak jauh, mahasiswa tidak bertemu secara langsung sehingga kemungkinan untuk menunda target maupun tugas akan semakin besar. Pembelajaran jarak jauh yang diterapkan pada mahasiswa memberikan berbagai macam problem sebagai efek samping salah satunya adalah prokrastinasi (Ningsih et al., 2020)

Menurut Ferrari et al. (1995), aspek- aspek perilaku prokrastinasi akademik terbagi menjadi 4 (empat) bahasan meliputi: menunda ketika akan memulai maupun ketika akan menyelesaikan suatu pekerjaan seperti tugas sekolah, keterlambatan dalam menyelesaikan tugas, kesenjangan waktu antara rencana dengan pelaksanaan tugas, kecenderungan untuk melakukan aktivitas lain yang dipandang lebih menyenangkan dan tidak membosankan. Ferrari et al. (1995) juga menjelaskan bahwa perilaku prokrastinasi akademik terbagi menjadi 2 (dua) faktor, yaitu faktor internal dan faktor eksternal. Faktor internal meliputi kesehatan atau kondisi fisik individu dan kondisi psikologis individu, sedangkan faktor eksternal meliputi pola asuh orang tua dan kondisi lingkungan (Ghufron \& Walgito, 2003).

Menurut Steel (2007), para mahasiswa yang melakukan prokrastinasi mengetahui akan dampak negatif yang akan diperoleh saat mereka melakukan prokrastinasi. Seperti dinyatakanoleh Ferrari et al. (1995), ketika melakukan prokrastinasi ada berbagai konsekuensi yang muncul di antaranya yaitu menambah beban pikiran, mudah tertekan dengan berbagai hal, tidak percaya diri serta berkurangnya mutu hidup sehingga akan berpengaruh negatif bagi individu yang melakukan prokrastinasi akademik. Prokrastinasi yang dilakukan dalam penyusunan skripsi juga akan memiliki dampak buruk bagi mahasiswa seperti terbuangnya waktu secara cuma-cuma, tidak memberikan hasil yang maksimal hingga kemungkinan untuk tidak menyelesaikan skripsi tepat waktu.

Berdasarkan berbagai fenomena yang telah dipaparkan, dapat disimpulkan bahwa masalah prokrastinasi merupakan salah satu dampak dari kegiatan pembelajaran jarak jauh pada mahasiswa tingkat akhir yang sedang mengerjakan skripsi. Permasalahan prokrastinasi ini apabila tidak segera diatasi, dikhawatirkan para mahasiswa akan semakin lama mencapai kelulusan. Hal ini secara tidak langsung akan berdampak pada masa depan mahasiswa dan 
citra perguruan tinggi tempat mereka belajar. Penelitian ini bertujuan untuk mengetahui gambaran prokrastinasi akademik mahasiswa tingkat akhir yang sedang mengerjakan skripsi dalam masa pandemi COVID-19.

\section{Metode}

Penelitian ini merupakan jenis penelitian survei. Penelitian survei merupakan salah satu bentuk penelitian kuantitatif yang dapat digunakan untuk mengetahui pendapat, keyakinan atau karakteristik suatu populasi (Creswell, 2013).

\section{Sampel}

Populasi dalam penelitian ini adalah mahasiswa tingkat akhir yang sedang mengerjakan skripsi di sebuah program studi di salah satu universitas negeri di Surabaya angkatan 2014, 2015, 2016 dan 2017. Penelitian menggunakan sampel jenuh, yaitu menggunakan seluruh mahasiswa tingkat akhir yang mengerjakan skripsi. Jumlah mahasiswa tingkat akhir yang sedang mengerjakan skripsi sejumlah 224 mahasiswa yang terbagi menjadi 30 mahasiswa untuk uji coba dan 194 mahasiswa untuk penelitian.

\section{Pengumpulan Data}

Teknik pengambilan data yang digunakan dalam penelitian ini adalah dengan menggunakan metode angket atau kuesioner yang berisi beberapa daftar pernyataan dimana responden diminta untuk memilih salah satu alternatif jawaban. Angket digunakan untuk mengukur prokrastinasi akademik terhadap responden. Penelitian ini menggunakan angket berbentuk google form yang disebarkan secara online.

Instrumen penelitian yang digunakan merujuk kepada teori prokrastinasi akademik. Peneliti menyusun instrumen perilaku prokrastinasi akademik yang dikembangkan oleh Ferrari et al. (1995) meliputi perilaku menunda ketika akan menyelesaikan suatu pekerjaan seperti tugas sekolah, kelambanan dalam menyelesaikan tugas, kesenjangan antara waktu perencanaan dan waktu pengerjaan tugas, dan kecenderungan dalam melakukan aktivitas lain yang dipandang lebih menyenangkan dan tidak membosankan. Instrumen penelitian ini dibuat dalam model skala likert yang terbagi dalam dua jenis, yaitu pernyataan favorable (f) dan pernyataan unfavorable (uf). Terdapat empat pilihan jawaban dalam kuesioner yaitu sangat setuju (SS), setuju (S), tidak setuju (TS), sangat tidak setuju (STS).

Uji validitas yang digunakan dalam penelitian ini adalah validitas isi yang merupakan validitas yang dilakukan melalui pengujian terhadap isi tes dengan analisa rasional serta sejauhmana aitem-aitem tes mewakili komponen-komponen dalam keseluruhan isi objek yang hendak diukur dan sejauhmana aitem-aitem tes tersebut mencerminkan ciri-ciri perilaku yang hendak diukur. Aitem-aitem dalam penelitian ini dikatakan valid apabila memiliki skor aitem lebih dari sama dengan 0,3 (Azwar, 2017). Berdasarkan hasil uji coba pada skala yang telah dibuat pada 30 responden, skala prokrastinasi akademik memiliki 44 pernyataan yang valid dan dapat digunakan untuk mengambil data.

Menurut Sugiyono (2016), hasil penelitian yang reliabel ditunjukkan dari adanya kesamaan data dalam waktu yang berbeda. Koefisien reliabilitas berkisar diantara 0 sampai dengan 1,00. Instrumen dikatakan sangat reliabel apabila hasil reliabilitasnya mendekati 1. Semakin tinggi koefisien reliabilitas mendekati 1,00, semakin tinggi reliabilitasnya (Azwar, 2017). Skala perilaku prokrastinasi akademik penelitian ini memiliki nilai reliabilitas dengan Alpha Cronbach sebesar 0,959.

\section{Analisis Data}

Analisis data dalam penelitian ini menggunakan statistik deskriptif dengan melihat pada persentase subjek (rata-rata dan standar deviasi) melalui program SPSS 
25.0 for windows sehingga dapat mengklasifikasikan prokrastinasi akademik mahasiswa yang tinggi, sedang dan rendah

\section{Hasil}

Penelitian ini bertujuan untuk mengkaji gambaran prokrastinasi akademik pada mahasiswa tingkat akhir yang sedang mengerjakan skripsi dalam masa pandemi COVID-19. Skala prokrastinasi akademik memiliki 44 pernyataan yang valid dan dapat digunakan untuk mengambil data. Skor tertinggi pada jawaban pernyataan tersebut adalah empat dan skor terendah adalah satu. Berdasarkan dari hal tersebut maka kemungkinan skor tertinggi yang bisa dicapai oleh subjek penelitian adalah 180 dan skor terendah yang bisa dicapai oleh subjek penelitian adalah 45 .

Tabel 1. Hasil Uji Statistik Deskriptif

\begin{tabular}{lcc}
\hline & & Prokrastinasi \\
\hline $\mathrm{N} \quad$ Valid & 194 \\
& Missing & 0 \\
Mean & 110.11 \\
Median & 110.50 \\
Mode & $104^{\mathrm{a}}$ \\
Minimum & 48 \\
Maximum & 160 \\
\hline
\end{tabular}

Berdasarkan hasil pengumpulan data yang telah dilakukan maka diperoleh skor tertinggi pada skala prokrastinasi akademik yang diperoleh subjek penelitian sebesar 160. Skor terendah yang diperoleh subjek penelitian sebesar 48. Hasil analisis statistik deskriptif menunjukkan nilai mean sebesar 110.11, median sebesar 110.50, modus sebesar 104, dan standard deviation 20.19 .

Tabel 2. Hasil Uji Tiap Aspek variabel

\begin{tabular}{lc}
\hline \multicolumn{1}{c}{ Aspek } & Mean \\
\hline $\begin{array}{l}\text { Menunda dalam memulai dan } \\
\text { menyelesaikan }\end{array}$ & 29.55 \\
$\begin{array}{l}\text { Keterlambat dalam } \\
\text { mengerjakan }\end{array}$ & 27.68 \\
$\begin{array}{l}\text { Kesenjangan waktu antara } \\
\text { rencana dan kinerja aktual }\end{array}$ & 24.26 \\
$\begin{array}{l}\text { Melakukan aktivitas yang lebih } \\
\text { menyenangkan }\end{array}$ & 28.60 \\
\hline
\end{tabular}

Prokrastinasi akademik terdiri dari empat aspek. Aspek menunda dalam memulai dan menyelesaikan skripsi memiliki rata-rata sebesar 29.55, aspek keterlambatan dalam mengerjakan skripsi sebesar 27.68, aspek kesenjangan waktu antara rencana dan kinerja aktual sebesar 24.26 dan aspek melakukan aktivitas yang lebih menyenangkan sebesar 28.60. Hasil pene-

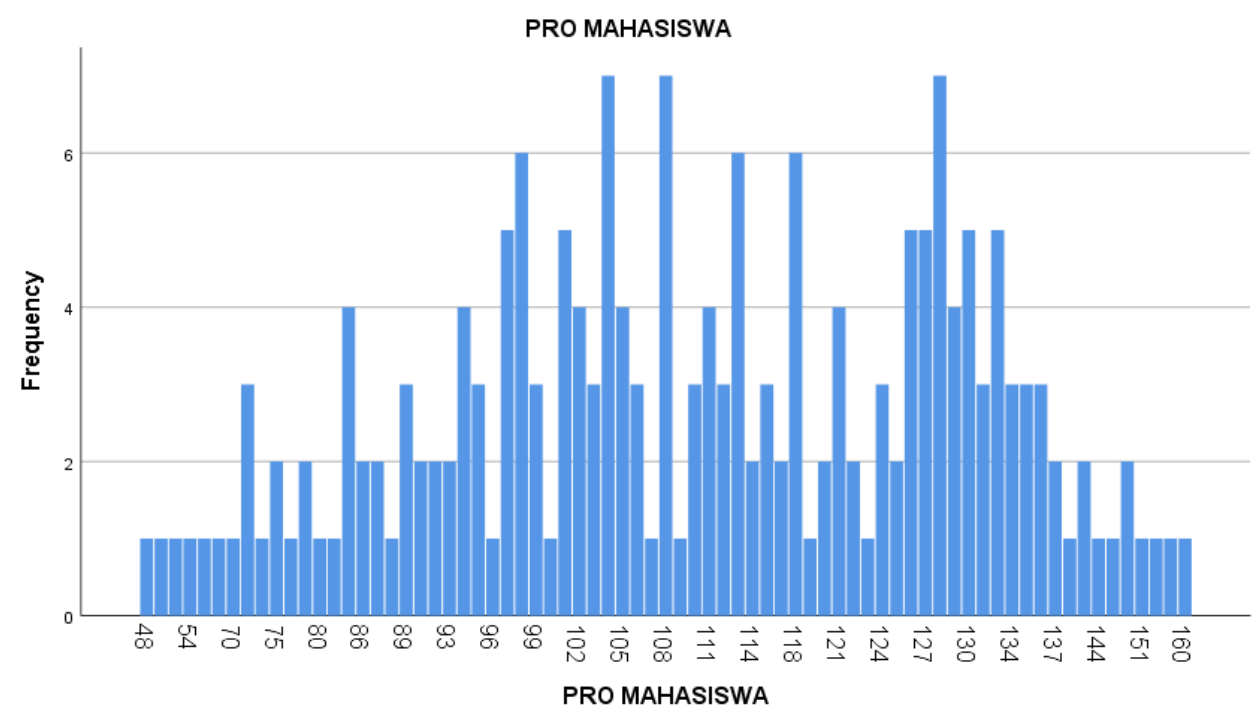

Gambar 1. Hasil prokrastinasi akademik mahasiswa Tingkat Akhir 
litian ini menunjukkan secara keseluruhan yang terkategori sedang dengan jumlah 140 mahasiswa atau $72 \%$ dari keseluruhan subjek penelitian. Terdapat 27 mahasiswa atau $14 \%$ yang termasuk dalam kategori tinggi dan terdapat 27 mahasiswa atau $14 \%$ yang termasuk dalam kategori rendah.

Berdasarkan variasi jenis kelamin, $77,84 \%$ merupakan mahasiswa perempuan dan $21,16 \%$ merupakan mahasiswa lakilaki serta baik laki-laki maupun perempuan sama-sama mayoritas berada pada kategori sedang. Mahasiswa laki-laki memiliki presentase yang lebih besar pada kategori tinggi, yaitu $16 \%$ sedangkan hanya terdapat $13 \%$ mahasiswa perempuan. Sebaliknya, persentase mahasiswa perempuan pada kategori prokrastinasi akademik rendah lebih besar daripada laki-laki yaitu $15 \%$ dan kategori prokrastinasi akademik rendah pada laki-laki yaitu $12 \%$.

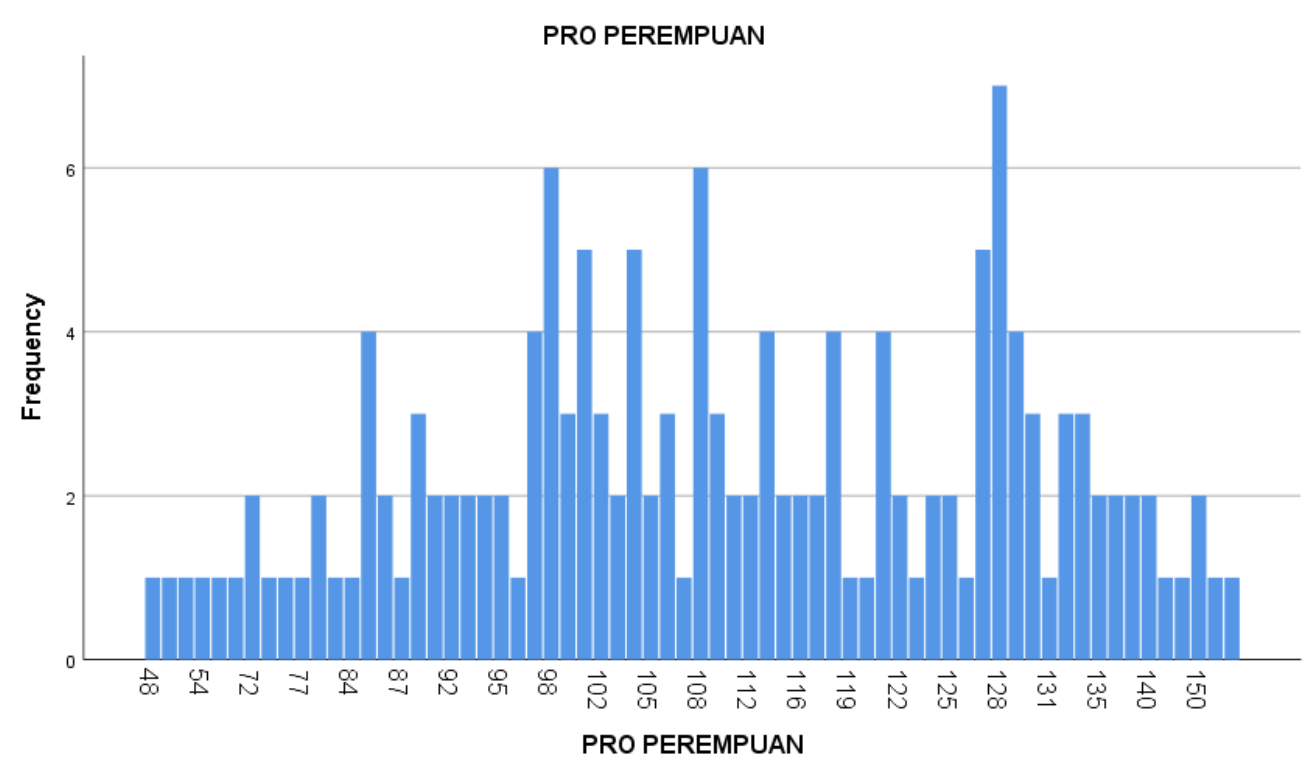

Gambar 2. Hasil Prokrastinasi Akademik Mahasiswa Tingkat Akhir Perempuan

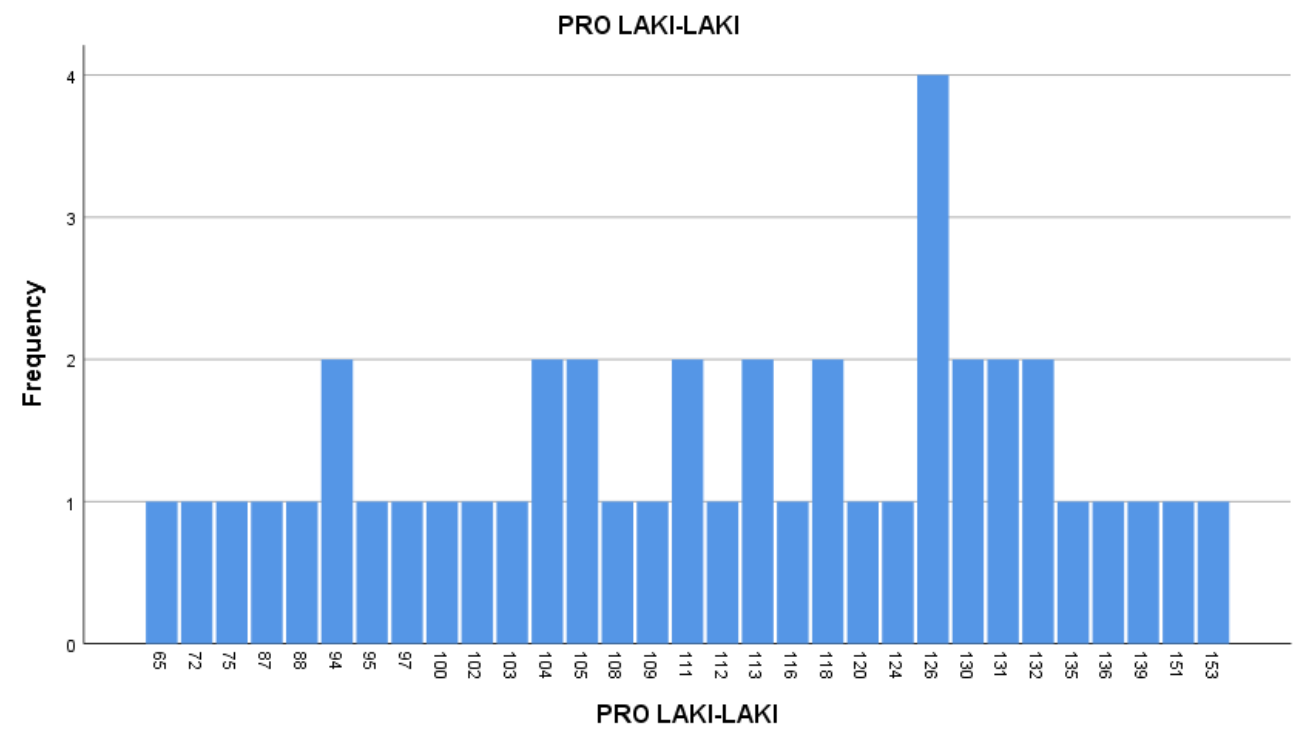

Gambar 3. Hasil Prokrastinasi Akademik Mahasiswa Tingkat Akhir Laki-Laki 
Dalam hal tahun angkatan masuk kuliah, tingkat prokrastinasi mahasiswa angkatan 2014 berada pada kategori tinggi (25\%) dan pada kategori sedang sebesar $75 \%$. Ini artinya prokrastinasi pada mahasiswa 2014 berada pada kategori tinggi dan sedang. Sementara pada mahasiswa ang- katan 2015, secara keseluruhan mahasiswa berada pada kategori sedang. Sementara pada mahasiswa angkatan 2016, yang berada pada kategori tinggi sebesar 3\%, pada kategori sedang sebesar $86 \%$ dan pada kategori rendah sebesar $11 \%$.

Berdasarkan tahun angkatan, mayori-

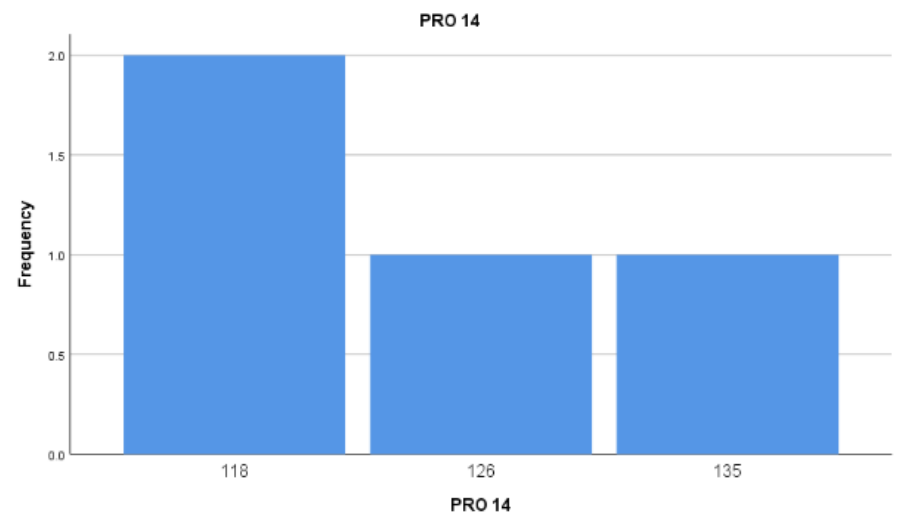

Gambar 4. Hasil Prokrastinasi Akademik Mahasiswa Tingkat Akhir Angkatan 2014

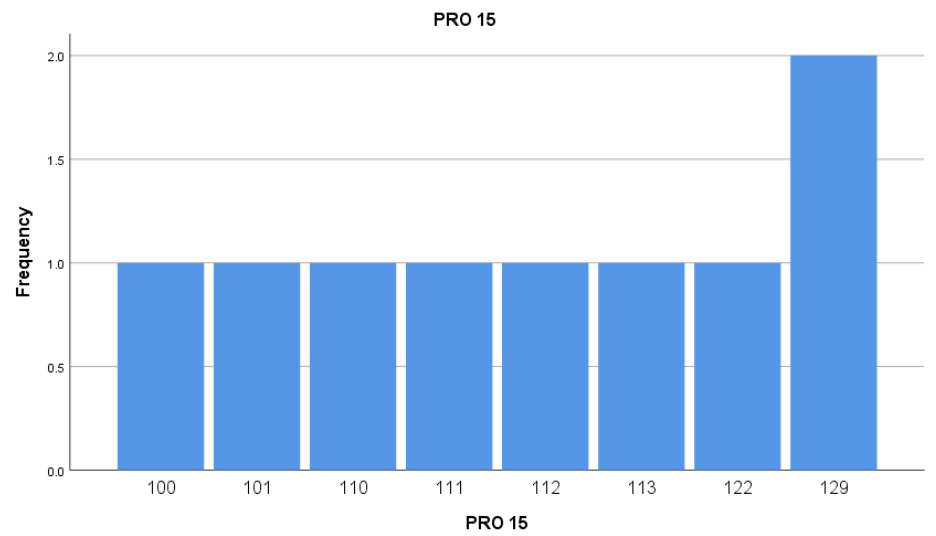

Gambar 5. Hasil Prokrastinasi Akademik Mahasiswa Tingkat Akhir Angkatan 2015

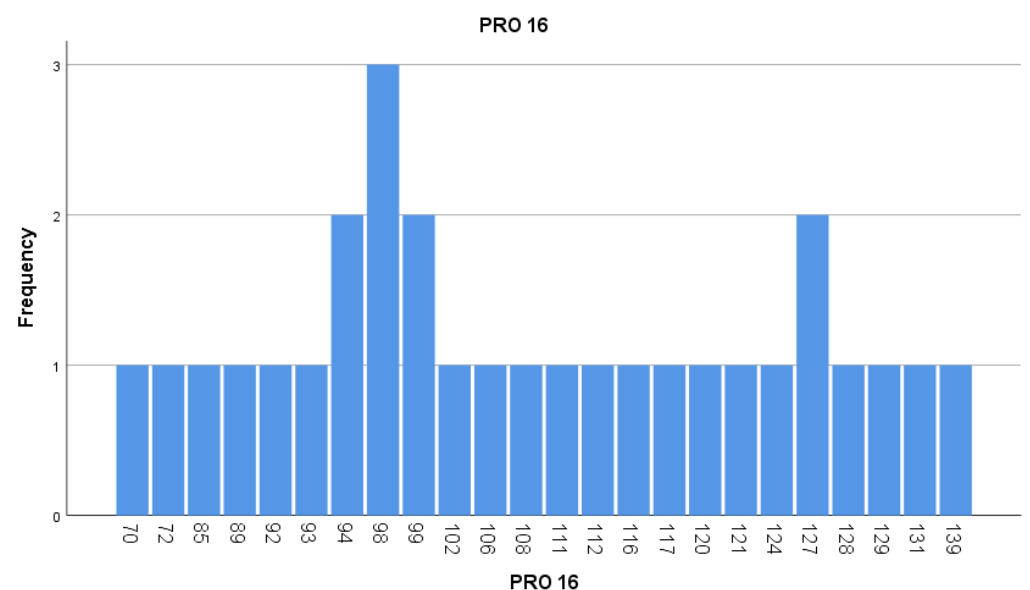

Gambar 6. Hasil Prokrastinasi Akademik Mahasiswa Tingkat Akhir Angkatan 2016 


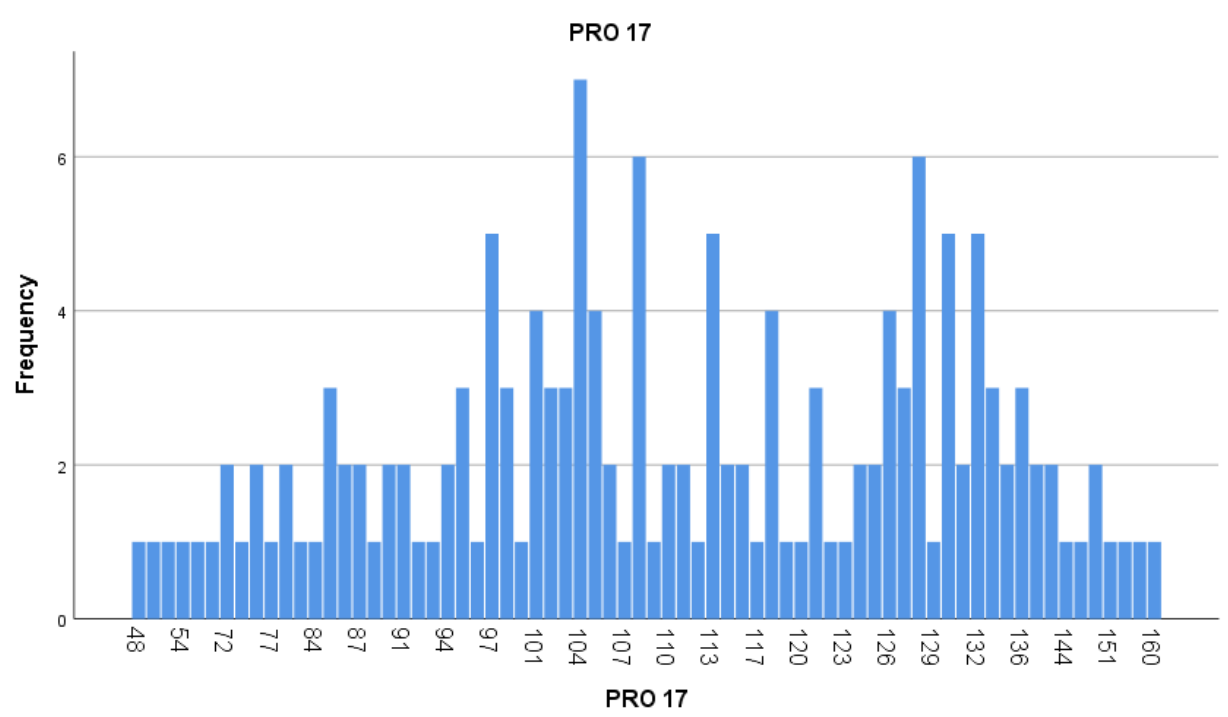

Gambar 7. Hasil Prokrastinasi Akademik Mahasiswa Tingkat Akhir Angkatan 2017

tas berasal dari angkatan tahun 2017, yaitu sebesar 78,35\%, angkatan 2014 sebesar 2,06\%, angkatan 2015 sebesar 4,64\%, dan angkatan 2016 sebesar $14,95 \%$ dari total mahasiswa tingkat akhir yang sedang mengerjakan skripsi. Hasil analisis menunjukkan prokrastinasi akademik pada angkatan 2017 yang berada dalam kategori sedang adalah paling tinggi dibandingkan angkatan lain. Pada angkatan 2017, mahasiswa yang berada pada kategori tinggi sebesar $16 \%$, pada kategori sedang sebesar $68 \%$ dan pada kategori rendah sebesar $16 \%$.
Berdasarkan tempat tinggal selama kuliah, $61,86 \%$ mahasiswa tinggal dengan orang tua atau keluarga dan $38,14 \%$ mahasiswa tidak dengan keluarga (kos, kontrak, lainnya). Mahasiswa yang tinggal dengan keluarga memiliki prokrastinasi akademik berada pada kategori sedang yaitu $68 \%$, pada kategori tinggi sebesar $14 \%$ dan pada kategori rendah sebesar $18 \%$. Pada mahasiswa yang tidak tinggal dengan keluarga, kategori prokrastinasi tingkat sedang sebesar $78 \%$, kategori tinggi sebesar $14 \%$, dan $8 \%$ pada kategor rendah.

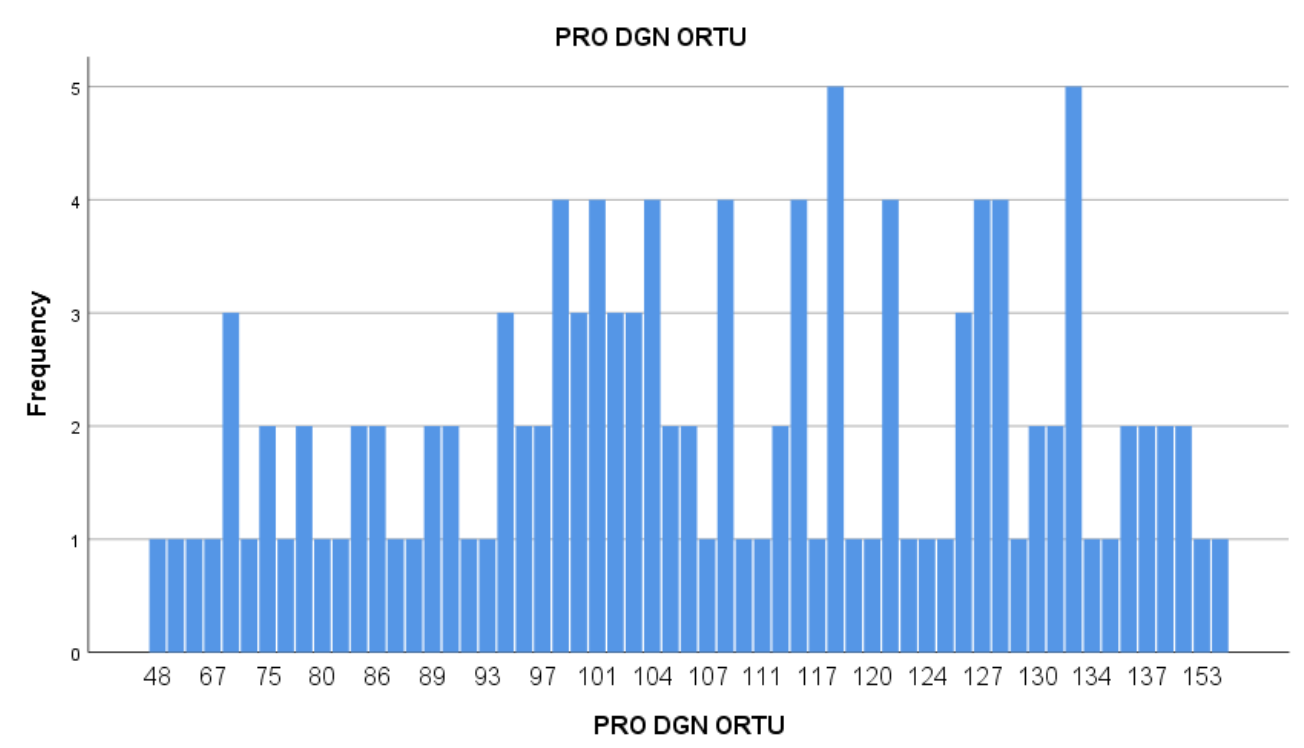

Gambar 11. Prokrastinasi Akademik Mahasiswa Tingkat Akhir yang Tinggal dengan Keluarga 


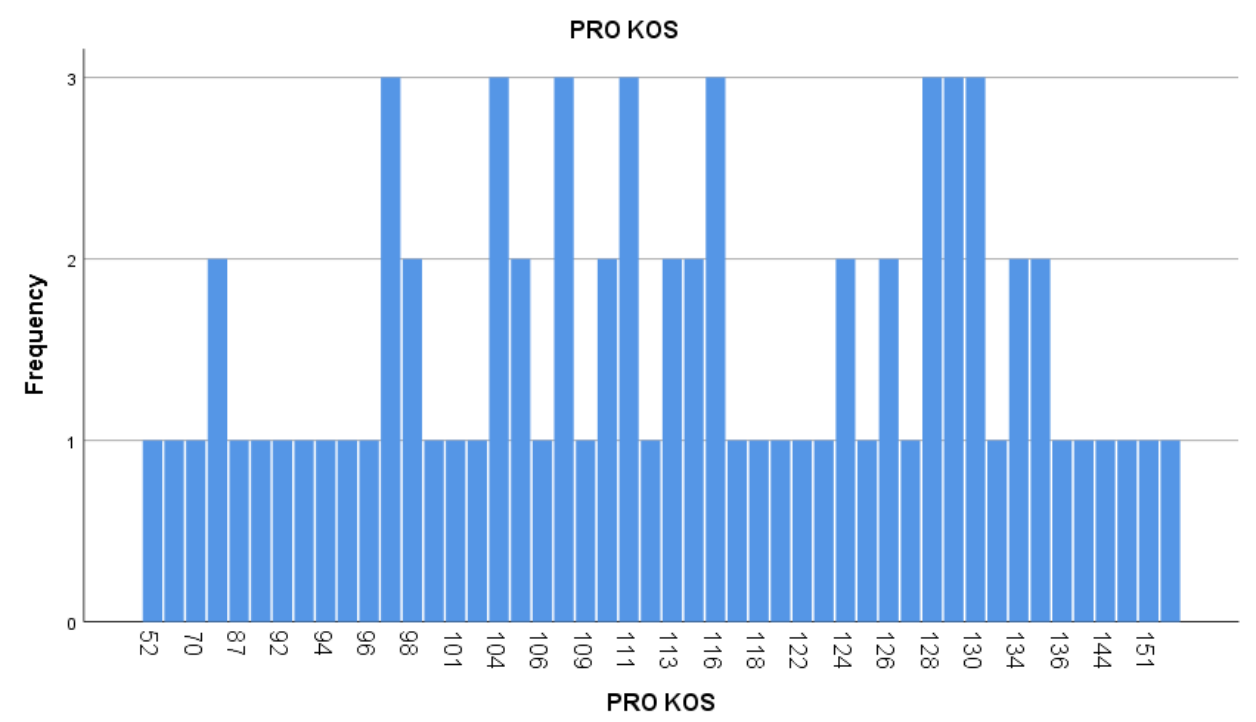

Gambar 12. Prokrastinasi Akademik Mahasiswa Tingkat Akhir yang Tidak Tinggal dengan Keluarga

\section{Pembahasan}

Hasil temuan penelitian ini menunjukkan mahasiswa secara umum melakukan prokrastinasi akademik selama menyelesaikan tugas akhir di masa pandemi. Pandemi COVID-19 yang memaksa mahasiswa untuk menjalani pembelajaran jarak jauh berkontribusi pada prokrastinasi tersebut. Aspek dominan yang menyebabkan munculnya prokrastinasi akademik tersebut adalah menunda dalam memulai dan menyelesaikan skripsi. Penundaan tugas ini merupakan ketidaktepatan waktu dimana terdapat perbedaan antara niat dan perilaku serta adanya preferensi untuk melakukan aktivitas lain (Schouwenburg, 1995).

Prokrastinasi merupakan perilaku yang tidak diharapkan terjadi dalam dunia akademik karena dapat menimbulkan konsekuensi berupa tidak berjalannya kemajuan akademik (Burka \& Yuen, 1983; LaForge, 2005). Pada mahasiswa tingkat akhir, prokrastinasi ini merupakan hambatan dalam mencapai tujuan akhir perkuliahan, yaitu menyelesaikan tugas akhir dan lulus studi. Sistem perkuliahan tatap muka yang berubah menjadi pembelajaran online di masa pandemi COVID-19 memberikan banyak perubahan dalam kegiatan belajar mahasis- wa termasuk dalam penyelesaian skripsi.

Prokrastinasi akademik menurunkan kualitas maupun kuantitas dari penyelesaian skripsi pada mahasiswa tingkat akhir yang pada akhirnya dapat dapat berujung pada stres. Secara umum, prokrastinasi dapat menurunkan kualitas hidup individu yang melakukan prokrastinasi (Cox \& Read, 1989). Hal ini sesuai dengan penelitian Mulyana et al. (2015) yang menemukan bahwa prokrastinasi akademik dapat menambah tingkat stres yang berakibat pada kecemasan mahasiswa. Hal senada juga diungkap Romash (2020) yang melaporkan bahwa pandemi ini merupakan situasi yang dapat menyebabkan stres serta gangguan emosi dan perilaku lain pada mahasiswa kedokteran.

Pembelajaran online yang membatasi interaksi fisik menyebabkan berkurangnya interaksi sosial, sehingga komunikasi baik verbal maupun nonverbal tidak dapat dilakukan secara optimal dengan dosen. Hal ini menyebabkan mahasiswa yang sedang mengerjakan skripsi melakukan penundaan terhadap pengerjaan skripsi yang menjadi tagihan pada akhir perkuliahannya dan mengalami kebingungan akan target yang akan dicapai, hingga kesulitan dalam memutuskan sesuatu. Hal ini diungkap oleh 
Rizkyani dan Tonih (2020) yang menyatakan bahwa salah satu indikator dominan yang dapat menyebabkan munculnya prokrastinasi akademik adalah gangguan perhatian. Risdiantoro et al. (2016) juga menyatakan bahwa individu yang melakukan perilaku prokrastinasi cenderung akan memiliki rasa cemas, takut mengalami kegagalan, sulit untuk membuat keputusan, selalu mengalami ketergantungan, kurang berani mengambil resiko, tidak bisa menunjukkan otonomi, sulit untuk beradaptasi, sulit untuk memberikan penilaian terhadap personal dan kompetensi diri, membenci adanya tugas, tidak tegas, serta melawan aturan. Prokrastinator yang sukses setelah melakukan prokrastinasi juga cenderung akan mengulang pola perilakunya (Ferrari et al., 1995; Tuckman, 2005).

Mahasiswa laki-laki dan perempuan melakukan prokrastinasi akademik pada tingkatan yang sama. Hal ini disebabkan oleh salah satu faktor yang menentukan perilaku prokastinasi adalah jenis kelamin (Ghufron \& Walgito, 2003). Nilakantie dan Endah (2014) mengungkapkan bahwa jenis kelamin laki-laki maupun perempuan memiliki tingkat prokrastinasi akademik yang sama. Mahasiswa tingkat akhir yang sedang menyelesaikan skripsi dihadapkan pada lingkungan akademis yang sama yaitu bimbingan pengerjaan skripsi secara online akibat adanya pandemi COVID-19 yang menyebabkan kategori yang sama pada tingkat prokrastinasi mahasiswa berdasarkan jenis kelamin. Mahasiswa laki-laki maupun perempuan sama-sama dituntut untuk mampu mengerjakan skripsi secara mandiri dengan bimbingan dosen secara online. Hal ini menjadi berbeda ketika sebelum adanya pandemi COVID-19 dimana pembimbingan skripsi dilakukan secara offline sehingga mahasiswa dan dosen dapat bertemu secara langsung dan melakukan diskusi secara efektif mengenai hambatan dalam pengerjaan skripsi.

Dalam hal tahun angkatan, prokrastinasi akademik mahasiswa juga tidak menunjukkan perbedaan berarti dimana secara keseluruhan responden penelitian ini ratarata berada pada level sedang. Kategori sedang pada angkatan 2017 lebih banyak daripada angkatan lainnya disebabkan mayoritas mahasiswa yang belum menyelesaikan skripsi adalah dari angkatan 2017. Mahasiswa tingkat akhir yang sedang menyelesaikan skripsi cenderung melakukan prokrastinasi disfungsional, yaitu penundaan yang tidak bertujuan yang berkibat buruk dan menimbulkan masalah (Ferrari et al., 1995). Solomon dan Rothblum (1984) menyatakan bahwa bertambahnya lama masa studi merupakan salah satu penyebab dari prokrastinasi dalam dunia akademik.

Mahasiswa yang menempuh pendidikan, tidak sedikit yang berasal dari luar kota tempat kuliah. Mahasiswa yang tidak tinggal dengan orang tua maupun keluarga melakukan prokrastinasi akademik lebih tinggi daripada yang tinggal dengan orang tua. Faktor eksternal merupakan salah satu faktor yang mempengaruhi prokrastinasi akademik pada mahasiswa. Kondisi lingkungan merupakan salah satu faktor eksternal yang muncul dikarenakan adanya stimulus tertentu yang bersifat sadar maupun tidak sadar dari sekitar individu tersebut (Ghufron \& Walgito, 2003). Prokrastinasi mahasiswa yang tidak tinggal dengan orang tua maupun keluarga terlihat lebih tinggi dari yang tinggal dengan keluarga. Hal ini terjadi karena mahasiswa dapat lebih bebas memilih melakukan aktivitas lain yang lebih menyenangkan tanpa pengawasan keluarga. Mahasiswa yang merasa tidak dapat menghadapi kesulitan dan hambatan dalam penyelesaian skripsinya, akhirnya berusaha untuk menghindar dari pengerjaan skripsi dengan berbagai alasan (Lasmono et al., 2008).

Pembelajaran jarak jauh secara online yang diberlakukan selama pandemi saat ini memiliki dampak besar pada mahasiswa tingkat akhir yang sedang mengerjakan skripsi. Pandemi COVID-19 menimbulkan dampak negatif pada perilaku prokrastinasi akademik dan telah terbukti memiliki 
dampak negatif pada kinerja akademik (Suhadianto et al., 2020). Mahasiswa yang melakukan prokrastinasi akademik mengetahui akibat dari penundaan yang dilakukannya. Hal ini selaras dengan definisi prokrastinasi akademik dari Senecal et al. (dalam Wolters, 2003) bahwa individu yang melakukan perilaku prokrastinasi memahami apa yang perlu dilakukannya, dan mungkin ingin melakukan tugas-tugas akademik yang harus dilakukannya, tetapi belum berhasil melakukan aktivitas sesuai dengan keinginan dan harapannya. Prokrastinasi merupakan kebiasaan yang sifatnya situasional, dan relatif stabil dalam lingkungan akademik, yang diistilahkan dengan state procrastination (Kartadinata \& Sia, 2008). Mahasiswa memiliki ciri prokrastinasi demikian ketika melakukan penundaan dengan sengaja yang menjadi kebiasaan atau pola yang tetap dan dilakukan mahasiswa ketika menghadapi berbagai dinamika pengerjaan skripsi pada situasi pandemi saat ini.

Beberapa faktor yang melatarbelakangi prokrastinasi menurut Patrzek et al., 2012 antara lain berkaitan dengan ciri-ciri kepribadian meliputi gambaran diri negatif, avoidance, dan perfectionism; faktor yang berkaitan dengan kompetensi individu meliputi rendahnya regulasi diri, kurangnya keterampilan manajemen waktu, rendahnya keterampilan belajar, dan kurangnya pengetahuan; faktor afeksi meliputi kecemasan, frustrasi, perasaan tertekan; faktor kognitif meliputi kekhawatiran, takut gagal, dan keyakinan irasional; faktor learning history meliputi perilaku belajar, pengalaman belajar yang negatif; faktor kesehatan fisik dan mental, meliputi illness dan impairment; serta faktor persepsi terhadap karakteristik tugas, meliputi tingkat kesulitan tugas, beban tugas, tugas yang tidak menarik dan tidak menyenangkan.

Kondisi pandemi saat ini membuat mahasiswa cenderung menghindari sesuatu yang kurang menyenangkan dan lebih memilih kegiatan maupun aktivitas yang menyenangkan. Hal ini dikarenakan maha- siswa hanya dapat melakukan kegiatan di dalam rumah sehingga kebosanan sering dirasakan oleh mahasiswa. Prokrastinasi akademik ini membuat mahasiswa menunda tugas yang harus dikerjakannya dan pada akhirnya berpengaruh pada pencapaian prestasi akademik (Hurlock, 2014). Penundaan pengerjaan tugas akademik dapat mengganggu aktivitas proses pembelajaran, sehingga mahasiswa menjadi tidak maksimal dalam memanfaatkan waktu yang tersedia. Selain itu, faktor lain yang membuat mahasiswa cenderung melakukan prokrastinasi akademik adalah pemikiran irasional yang tidak tepat waktu, dan cenderung melakukan hal-hal yang lebih menyenangkan daripada menyelesaikan tugasnya (Fajhriani, 2020)

Prokrastinasi akademik tidak hanya sekedar lamanya waktu dalam menyelesaikan pengerjaan skripsi tetapi juga perilaku penundaan yang dilakukan konsisten oleh mahasiswa dimana ada kesenjangan antara niat dan perilaku yang dilakukan. Perilaku ini yang tidak efisien namun sering dipilih oleh mahasiswa. Mahasiswa memilih perilaku prokrastinasi karena merasa takut gagal, tidak menyukai tugas maupun adanya faktor lain seperti adanya sifat bergantung pada orang lain dan membutuhkan bantuan dalam pengambilan keputusan (Rizvi et al., 1997).

Perilaku prokrastinasi memiliki konsekuensi akademik yang cukup besar khususnya yang dilakukan oleh mahasiswa tingkat akhir akan terkait dengan kelulusan dan nama baik jurusan maupun perguruan tinggi. Salah satu upaya yang dapat dilakukan untuk menurunkan tingkat prokrastinasi mahasiswa adalah meningkatkan regulasi diri pada para mahasiswa. Hal ini juga dapat diterapkan pada mahasiswa tingkat akhir yang sedang mengerjakan skripsi. Siswa yang merasa dirinya sangat kompeten menggunakan strategi self regulated learning (penetapan tujuan dan perencanaan, manajemen waktu, strategi metakognitif) lebih sering dan lebih termotivasi secara intrinsik daripada siswa 
dengan kompetensi yang dirasakan lebih rendah serta kurang dalam melakukan penundaan dalam tugas (Pelikan et al., 2021). Mahasiswa juga dapat menerapkan manajemen waktu dalam pengerjaan skripsi dalam upaya mengurangi prokrastinasi akademik. Manajemen waktu memiliki pengaruh besar pada prokrastinasi akademik (Nisa et al., 2019).

Manajemen waktu yang buruk akan digolongkan pada perilaku prokrastinasi apabila dilakukan dengan sengaja walaupun individu yang melaku-kan perilaku prokrastinasi sadar bahwa ia membutuhkan waktu lebih banyak lagi untuk menyelesaikan tugasnya. Selain regulasi diri dan manajaemen waktu, mahasiswa juga dapat meningkatkan self efficacy. Penelitian yang telah dilakukan Hernandez et al. (2020) menunjukkan bahwa self efficacy mampu untuk mengurangi perilaku prokrastinasi akademik yang sering terjadi pada mahasiswa. Temuan yang sama dilaporkan oleh Klassen (2008) bahwa self efficacy menjadi variabel penting untuk menjadi solusi dari prokrastinasi akademik.

\section{Simpulan}

Berdasarkan hasil penelitian ini, dapat disimpulkan bahwa prokrastinasi akademik dilakukan oleh mahasiswa tingkat akhir yang sedang mengerjakan skripsi pada masa pandemi saat ini menunjukkan tingkatan sedang. Prokrastinasi akademik memiliki empat aspek yang mendasari yaitu perilaku menunda dalam memulai dan menyelesaikan, keterlambatan dalam mengerjakan, kesenjangan waktu antara rencana dan kinerja aktual dan melakukan aktivitas yang lebih menyenangkan. Di antara keempat aspek tersebut, perilaku menunda dalam memulai dan menyelesaikan skripsi merupakan perilaku dominan yang mendasari prokrastinasi akademik mahasiswa tingkat akhir.

\section{Saran}

Berdasarkan temuan penelitian ini, saran teoritis dapat diberikan terutama dalam penjelasan aspek yang dominan dalam variabel prokrastinasi akademik mahasiswa pada saat pandemi COVID-19. Hal ini dapat dijawab melalui analisis faktorial atas variabel yang diteliti. Peneliti yang mengkaji prokrastinasi akademik juga sebaiknya menspesifikasikan karakteristik sampel penelitiannya agar hasil yang didapatkan lebih reliabel. Peneliti selanjutnya juga disarankan untuk mengkombinasikan prokrastinasi akademik mahasiswa dengan variabel lain yang dapat mempengaruhinya terutama pada situasi pandemi.

Saran praktis untuk untuk menurunkan tingkat prokrastinasi mahasiswa adalah meningkatkan regulasi diri mahasiswa, menerapkan manajemen waktu yang efektif, dan meningkatkan efikasi diri mahasiswa. Upaya-upaya tersebut dapat dilakukan secara mandiri oleh mahasiswa melalui pengalaman belajar yang relevan dan dapat difasilitasi oleh perguruan tinggi melalui berbagai pelatihan dan layanan psikologis pada mahasiswa selama masa pandemi ini.

\section{Daftar Pustaka}

Argaheni, N. (2020). Sistematik review: dampak perkuliahan daring saat pandemi Covid-19 terhadap mahasiswa Indonesia. Jurnal Ilmiah Kesehatan dan Aplikasinya, 8(2), 99-108. https://jurnal.uns.ac.id/placentum/arti cle/download/43008/28002

Azwar, S. (2017). Reliabilitas dan validitas. Pustaka Belajar.

Burka, J., \& Yuen, L. (1983). Procrastination: why you do it, what to do about it. Da Capo. 
Cox, J. \& Read, R. (1989). Putting it off 'til later, procrastination: causes and corrections. Baylor Business Review, $7(3)$, $10-14$. https://www.proquest.com/openview /759dfb040783f6b91e994ce732a444 04/1?pqorigsite $=$ gscholar \&cbl $=36194$

Creswell, J. W. (2013). Research Design Pendekatan Kualitatif, Kuantitatif, dan Mixed (edisi terjemahan). Pustaka Pelajar.

Fajhriani, N. D. (2020). Academic procrastination of students. Abjadia: International Journal of Education, 5(2), 132-144. http://ejournal.uinmalang.ac.id/index.php/abjadia/articl e/download/9458/pdf

Ferrari, J., Johnson, J., \& McCown, W. (1995). Procrastination and task avoidance: Theory, research, and treatment. Springer Science \& Business Media.

Ghufron, M., \& Walgito, P. B. (2003). Hubungan kontrol diri dan persepsi remaja terhadap penerapan disiplin orangtua dengan prokrastinasi akademik (Unpublished Thesis). Universitas Gadjah Mada. https://repository.ugm.ac.id/61388/

Godfrey, M. (1991). Education, training and employment: what can planners $d o$ ? ILO \& ARTEP.

Handoyo, A. W., Afiati D., Yunika, D., \& Khairun, A. S. P. (2020). Prokrastinasi mahasiswa selama masa pembelajaran daring. Prosiding Seminar Nasional Pendidikan FKIP Universitas Sultan Ageng Tirtayasa, 3(1), 355-361. https://jurnal.untirta.ac.id/index.php/ psnp/article/download/9951/6463

Hernandez, Y. C. U., Fernando, O., Cueto, A., Shardin-Flores, N., \& Luy, C. A. (2020). Academic procrastination, self-esteem and self- efficacy in university students: comparative study in two Peruvian cities. International Journal of Criminology and Sociology, 9, 24742480.

https://www.researchgate.net/publica tion/348675574

Hurlock, E. (2014). Psikologi Perkembangan ( $5^{\text {th }}$ ed.). Erlangga.

Kartadinata, I., \& Sia, T. (2008). I Love You Tomorrow: Prokrastinasi Akademik dan Manajemen Waktu Iven Kartadinata dan Sia Tjundjing. Indonesian Psychological Journal, 23(2), 109-119. http://repository.ubaya.ac.id/id/eprint 123843

Klassen, M. R., Krawchuk L. L., \& Rajani, S. (2008). Academic procrastination of undergraduates: low self-efficacy to self-regulate predicts higher levels of procrastination. Contemporary Educational Psychology, 33, 915931.

https://doi.org/https://doi.org/10.101 6/j.cedpsych.2007.07.001

LaForge, M. C. (2005). Applying explanatory style to academic procrastination.

https://citeseerx.ist.psu.edu/viewdoc/ download?doi=10.1.1.124.1874\&rep $=$ rep1\&type=pdf

Lasmono, H., Nanik, \& Gunawinata, V. A. (2008). Perfeksionisme, prokrastinasi akademik, dan penyelesaian skripsi mahasiswa. ANIMA Indonesian Psychological Journal, 23(3), 257-276. http://repository.ubaya.ac.id/31260/7 /Perfeksionisme_Prokrastinasi\%20A kademik_AIPJ_023\%283\%29_256276_Gunawinata_.pdf

Mulyana, E., Mujidin, \& Bashori, K. (2015). Peran motivasi belajar, selfefficacy, dan dukungan sosial 
keluarga terhadap self-regulated learning pada siswa. Psikopedagogia, 4(1), 165-173. https://doi.org/http://dx.doi.org/10.12 928/psikopedagogia.v4i2.4480

Nilakantie, R., \& Endah, M. (2014). Perbedaan tingkat prokrastinasi akademik ditinjau dari jenis kelamin dan locus of control pada mahasiswa yang mengambil mata kuliah skripsi di Fakultas Psikologi Universitas Airlangga. Jurnal Psikologi Kepribadian dan Sosial, 3(1), 9-14. http://repository.unair.ac.id/id/eprint/ 106034

Ningsih, S., Yandri, H., Sasferi, N., \& Juliawati, D. (2020). An analysis of junior high school students' learning stress levels during the Covid-19 outbreak: Review of gender differences. Psychocentrum Review, 2(2), 69-76. https://doi.org/https://doi.org/10.265 39/pcr.22321

Nisa, N. K., Mukhlis, H., Wahyudi, D. A., \& Putri, R. (2019). Manajemen waktu dengan prokrastinasi akademik pada mahasiswa keperawatan. Journal of Psychological Perspective, 1(1), 2934.

https://ukinstitute.org/journals/jopp/a rticle/view/joppv1i104

Patrzek, J., Grunschel, C., \& Fries, S. (2012). Academic procrastination: The perspective of university counsellors. International Journal for the Advancement of Counselling, 34(3), 185-201. https://doi.org/10.1007/s10447-0129150-z

Pelikan, E. R., Lüftenegger, M., Holzer, J., Korlat, S., Spiel, C., \& Schober, B. (2021). Learning during COVID19: the role of self-regulated learning, motivation, and procrastination for perceived competence. Z Erziehungswiss, 24, 393-418.

https://doi.org/https://doi.org/10.100

7/s11618-021-01002-x

Prawiyogi, A. G., Purwanugraha, A., Fakhry, G., \& Firmansyah, M. (2020). Efektifitas pembelajaran jarak jauh terhadap pembelajaran siswa di SDIT Cendekia Purwakarta. Jurnal Pendidikan Dasar, 11(1), 94101.

https://doi.org/https://doi.org/10.210 09/JPD.011.10

Pychyl, T. A., Lee, J. M., Thibodeau, R., \& Blunt, A. (2000). Five days of emotion: An experience sampling study of undergraduate student procrastination. Journal of Social Behavior \& Personality, 15(5), 239254.

https://psycnet.apa.org/record/200210572-019

Risdiantoro, R., Iswinarti, \& Hasanati, N. (2016). Hubungan prokrastinasi akademik, stres akademik dan kepuasan hidup mahasiswa. Psychology \& Humanity, 19(20), 360-373.

https://mpsi.umm.ac.id/files/file/360$\% 20373 \% 20$ Rindra\%20Risdiantoro, $\%$ 20Iswinarti,\%20dan\%20Nida\%20 Hasanati.pdf

Rizkyani, A. M., \& Tonih, F. N. S. (2020). Hubungan antara self regulated learning dengan prokrastinasi akademik pada mahasiswa pendidikan kimia di masa pandemi Covid-19. EDUSAINS, 12(2), 252-258. http://journal.uinjkt.ac.id/index.php/e dusains/article/view/18175/pdf

Rizvi, A., Prawitasari, J., \& Soetjipto, H. (1997). Pusat kendali dan efikasi diri sebagai prediktor terhadap prokrastinasi akademik mahasiswa. Psikologika, 2(3), 51-66. https://doi.org/https://doi.org/10.208 
85/psikologika.vol2.iss3.art6

Romash, I. (2020). The nature of the manifestation of procrastination, level of anxiety and depression in medical students in a period of altered psycho-emotional state during forced social distancing because of pandemic Covid-19 and its impact on academic performance. MHGC Proceeding, 3(2). https://doi.org/HTTPS://DOI.ORG/1 0.32437/MHGCJ.V4I2.92

Schouwenburg, H. C. (1995). Academic procrastination: Theoretical notions, measurement, and research. The Plenum Series in Social/Clinical Psychology, 71-96. https://doi.org/https://doi.org/10.100 7/978-1-4899-0227-6_4

Solomon, L. \& Rothblum, E. (1984). Academic procrastination: frequwncy and cognitive behavioral correlates. Journal of Counseling Psychology, 31(4), 503-509. https://doi.org/https://doi.org/10.103 7/0022-0167.31.4.503

Steel, P. (2007). The nature of procrastination: A meta-analytic and theoretical review of quintessential self-regulatory failure. Psychological Bulletin, 133(1), 65-94. https://doi.org/10.1037/00332909.133.1.65

Sugiyono. (2016). Metode penelitian kuantitatif, kualitatif, dan $R \& D$. Alfa Beta.

Suhadianto, Arifiana, I. Y., Rahmawati, H., Hanurawan, F., \& Eva, N. (2020). Stop academic procrastination during Covid-19: Academic procrastination reduces subjective well-being. KnE Social
Sciences / International Conference of Psychology, 312-325. https://doi.org/https://doi.org/10.185 02/kss.v4i15.8220

Suryono, S. (2020). Manajemen pembelajaran berbasis daring dalam rangka memutus mata rantai penularan Covid-19 di perguruan tinggi swasta lembaga layanan perguruan tinggi (LLDIKTI) wilayah VII. Ed-Humanistics: Jurnal Ilmu Pendidikan, 5(1), 662-666. http://ejournal.unhasy.ac.id/index.ph p/ed-

humanistics/article/view/708/569

Tezer, M., Ulgener, P., Minalay, H., Ture, A., Tugutlu, U. \& Harper, M. G. (2020). Examining the relationship between academic procrastination behaviours and problematic internet usage of high school students during the Covid-19 pandemic period. Global Journal of Guidance And Counseling In Schools: Current Perspectives, 10(3), 142-256. https://doi.org/HTTPS://DOI.ORG/1 0.18844/GJGC.V10I3.5549

Tuckman, B. (2005). The relationship of academic procrastination, rationalizations, and performance in a web course with deadlines. Psychological Reports, 96(3_suppl), 1015-1021.

https://doi.org/https://doi.org/10.246 6/pr0.96.3c.1015-1021

Wolters, C. (2003). Understanding procrastination from a self-regulated learning perspective. Journal of Educational Psychology, 3(1), 179187.

https://psycnet.apa.org/record/200301605-016 